\title{
New flux based dose-response relationships for ozone for European forest tree species
}

\author{
P. Büker a, * , Z. Feng ${ }^{\text {b }}$, J. Uddling ${ }^{\text {c }}$, A. Briolat ${ }^{\text {a }}$, R. Alonso ${ }^{\text {d }}$, S. Braun ${ }^{\text {e }}$, S. Elvira ${ }^{\text {d }}$, G. Gerosa ${ }^{\text {, }}$, \\ P.E. Karlsson ${ }^{\mathrm{g}}$, D. Le Thiec ${ }^{\mathrm{h}}$, R. Marzuoli ${ }^{\mathrm{f}}$, G. Mills ${ }^{\mathrm{i}}$, E. Oksanen ${ }^{\mathrm{j}}$, G. Wieser ${ }^{\mathrm{k}}$, \\ M. Wilkinson ${ }^{1}$, L.D. Emberson ${ }^{\text {a }}$ \\ a Stockholm Environment Institute at York, Environment Department, University of York, Heslington, York, YO10 5DD, United Kingdom \\ ${ }^{\mathrm{b}}$ Research Centre for Eco-Environmental Science, Chinese Academy of Sciences, 18 Shuangqing Road, Haidan District, 100085 Beijing, China \\ ${ }^{c}$ Department of Biological and Environmental Sciences, University of Gothenburg, PO Box 461, 40530 Gothenburg, Sweden \\ ${ }^{\mathrm{d}}$ Ecotoxicology of Air Pollution, CIEMAT, Av. Complutense 40, 28040 Madrid, Spain \\ e Institut für Angewandte Pflanzenbiologie (IAP), Sandgrubenstraße 25/27, 4124 Schönenbuch, Switzerland \\ ${ }^{\mathrm{f}}$ Dipartimento di Matematica e Fisica "Niccolò Tartaglia", Università Cattolica del Sacro Cuore, via Musei 41, 25121 Brescia, Italy \\ g Swedish Environmental Research Institute, IVL, Box 5302, 40014 Gothenburg, Sweden \\ h UMR Ecologie et Ecophysiologie Forestières, INRA, Rue D'Amance, 54280 Champenoux, France \\ i Centre for Ecology and Hydrology, Environment Centre Wales, Deiniol Road, Bangor, Gwynedd, LL57 2UW, United Kingdom \\ ${ }^{j}$ Department of Biology, University of Eastern Finland, Post Box 111, 80101 Joensuu, Finland \\ ${ }^{\mathrm{k}}$ Department for Natural Hazards and Alpine Timberline, Federal Research and Training Centre for Forests, Natural Hazards and Landscape, Hofburg 1 , \\ 6020 Innsbruck, Austria \\ ${ }^{1}$ Centre for Sustainable Forestry \& Climate Change, Forest Research, Alice Holt Lodge, Farnham, Surrey, GU10 4LH, United Kingdom
}

\section{A R T I C L E I N F O}

\section{Article history:}

Received 19 December 2014

Received in revised form 30 April 2015

Accepted 27 June 2015

Available online 10 July 2015

\section{Keywords:}

Trees

Ozone flux

Dose-response relationships

Model-based risk assessment

\begin{abstract}
A B S T R A C T
To derive $\mathrm{O}_{3}$ dose-response relationships (DRR) for five European forest trees species and broadleaf deciduous and needleleaf tree plant functional types (PFTs), phytotoxic $\mathrm{O}_{3}$ doses (PODy) were related to biomass reductions. PODy was calculated using a stomatal flux model with a range of cut-off thresholds $(y)$ indicative of varying detoxification capacities. Linear regression analysis showed that DRR for PFT and individual tree species differed in their robustness. A simplified parameterisation of the flux model was tested and showed that for most non-Mediterranean tree species, this simplified model led to similarly robust DRR as compared to a species- and climate region-specific parameterisation. Experimentally induced soil water stress was not found to substantially reduce PODy, mainly due to the short duration of soil water stress periods. This study validates the stomatal $\mathrm{O}_{3}$ flux concept and represents a step forward in predicting $\mathrm{O}_{3}$ damage to forests in a spatially and temporally varying climate.
\end{abstract}

Crown Copyright $\odot 2015$ Published by Elsevier Ltd. All rights reserved.

\section{Introduction}

A large body of evidence has shown that ozone $\left(\mathrm{O}_{3}\right)$ causes damage to trees (Wittig et al., 2009; Matyssek et al., 2010). These $\mathrm{O}_{3}$

\footnotetext{
* Corresponding author.

E-mail addresses: patrick.bueker@york.ac.uk (P. Büker), fzz@rcees.ac.cn (Z. Feng), johan.uddling@bioenv.gu.se (J. Uddling), alan.briolat@york.ac.uk (A. Briolat), rocio.alonso@ciemat.es (R. Alonso), sabine.braun@iap.ch (S. Braun), susana.elvira@ciemat.es (S. Elvira),giacomo.gerosa@unicatt.it (G. Gerosa), pererik. karlsson@ivl.se (P.E. Karlsson), le_thiec@nancy.inra.fr (D. Le Thiec), riccardo. marzuoli@unicatt.it (R. Marzuoli), gmi@ceh.ac.uk (G. Mills), elina.oksanen@uef.fi (E. Oksanen), gerhard.wieser@uibk.ac.at (G. Wieser), matthew.wilkinson@forestry. gsi.gov.uk (M. Wilkinson), l.emberson@york.ac.uk (L.D. Emberson).
}

effects range from impacts such as visible injury on foliage (Schaub, 2005), decreasing leaf chlorophyll content and photosynthesis (Wittig et al., 2009), changes in carbon allocation (Paoletti et al., 2009) and biomass production (Wittig et al., 2009), premature leaf senescence (Pell et al., 1999), and altered tree water use (Sun et al., 2012). By synthesising information expressed as $\mathrm{O}_{3}$ flux based dose-response relationships (DRR) derived from fieldexperiments, critical levels (CLs) have been identified above which $\mathrm{O}_{3}$ damage would be expected to occur (LRTAP Convention, 2010; Mills et al., 2011). The United Nations Convention on LongRange Transboundary Air Pollution (LRTAP Convention) has used such CLs as a policy tool to identify areas of CL exceedance across Europe and subsequently to formulate European emission reduction strategies to improve air quality. 
This study presents the next stage in the derivation of DRR for forest trees, which use the accumulated stomatal $\mathrm{O}_{3}$ flux above a threshold ' $y$ ' as the dose metric (Emberson et al., 2007), often referred to as PODy (Phytotoxic Ozone Dose above a threshold ' $y$ '), and the relative change in annual whole tree biomass production as the response metric (Karlsson et al., 2007). Current CLs for forest trees are based on an analysis performed by Karlsson et al. (2007) on Norway spruce (27 data points from 3 countries and 8 experiments) and beech/birch (38 data points from 3 countries and 14 different experiments) and were set to values for which there was a $>95 \%$ confidence of finding a significant effect at the percentage loss chosen (LRTAP Convention, 2010; Mills et al., 2011). Since the publication of Karlsson et al. (2007), additional experimental data have become available that extend the species under investigation and increase the range of environmental conditions under which the fumigation or filtration experiments were performed. In addition, new methods to assess the influence of soil moisture on stomatal $\mathrm{O}_{3}$ flux have been developed (Büker et al., 2012).

In performing this re-analysis including all currently available forest tree data, we addressed the following sources of uncertainty in flux-effect modelling for forest tree species: i. the parameterisation of the stomatal flux model; ii. the choice of the ' $y$ ' threshold (which is considered to statistically represent the plants' ability to detoxify a certain level of $\mathrm{O}_{3}$ dose (Pleijel et al., 2007)); iii. the influence of reduced water-availability on stomatal $\mathrm{O}_{3}$ flux and; iv. whether particular groupings of species, e.g. according to plant functional types (PFTs), with similar $\mathrm{O}_{3}$ sensitivities can be identified. We also compared regression functions based on the same updated dataset using the updated flux methodology with those using the formerly accepted concentration-based approach $\left(\mathrm{AOT} 40^{1}\right)$.

To investigate the parameterisation of the flux model, this study applied two different methods to estimate stomatal $\mathrm{O}_{3}$ fluxes. The first method was that used previously by Karlsson et al. (2007), but with updates to include new parameterisations defined in the 2010 revision of the UNECE Mapping manual (LRTAP Convention, 2010). These 'real species' parameterisations incorporate new data to define parameter values and also identify climate specific parameterisations to account for different species ecotypes. A second method tested the suitability of a simplified parameterisation, i.e. standard functions that describe the effect of light, vapour pressure deficit and temperature on stomatal conductance $\left(g_{s}\right)$ irrespective of species, called simplified parameterisation or simple model from hereon. Application of this method was used to test the hypothesis that a simplified parameterisation of the multiplicative $g_{s}$ model leads to a similarly robust DRR as compared to the 'real species' parameterisation. As such it examined whether there is a need for a rigorous species-specific parameterisation of the model, which often complicates large-scale application of the flux based method both for flux-effect as well as total $\mathrm{O}_{3}$ deposition estimation.

This study also presented the opportunity to compile new dose-response functions and datasets for two species (i.e. Holm oak and poplar) not considered in Karlsson et al. (2007). This allowed a more thorough investigation of the uncertainty in the current CLs related to the selection of the ' $y$ ' threshold. Karlsson et al. (2007) used a single ' $y$ ' value of $1.6 \mathrm{nmol} \mathrm{O} \mathrm{O}^{-2} \mathrm{~s}^{-1}$ based on a previous analysis (Karlsson et al., 2004), which found that this value gave higher $\mathrm{R}^{2}$ values for flux-effect relationships when compared with thresholds of $0.0,3.2$ and $4.8 \mathrm{nmol} \mathrm{O}_{3} \mathrm{~m}^{-2} \mathrm{~s}^{-1}$. Since it is more statistically robust to test a number of ' $y$ ' thresholds (Feng et al., 2012), the analysis presented here set out to trial a far wider and incrementally refined number of ' $y$ ' threshold values than has

${ }^{1}$ AOT40 $=$ Ozone concentrations accumulated over a threshold of $40 \mathrm{ppb}$. been performed previously for forest tree species.

Another key area of uncertainty investigated here is the influence of reduced water availability on PODy and hence $\mathrm{O}_{3}$ sensitivity. Some of the new datasets are derived from experimental $\mathrm{O}_{3}$ fumigations or filtrations conducted under varying levels of water supply. This allows the effect of reduced water availability on PODy to be investigated using a new soil water balance method described in Büker et al. (2012). This is particularly important as the exclusion of data representing non-optimal water supply, which is known to reduce $\mathrm{g}_{\mathrm{s}}$ (Büker et al., 2012) and therefore stomatal $\mathrm{O}_{3}$ flux, has been cited as reason why the stomatal flux approach sometimes does not provide a substantial improvement of DRR developed using the concentration based AOT40 index (e.g. Karlsson et al., 2007).

Finally, this study also investigated whether species groupings of $\mathrm{O}_{3}$ sensitivity can be defined. Past studies have been rather inconclusive in defining DRR that are able to represent different tree PFTs. For example, Karlsson et al. (2004, 2007) found Norway spruce, Scots pine and birch/beech to be more sensitive than Aleppo pine and oak such that no obvious distinction could be made between broadleaf and needleleaf trees. In contrast, a metaanalysis performed for forest trees by Wittig et al. (2009) found evidence for gymnosperms being less sensitive than angiosperms when related to $\mathrm{O}_{3}$ concentrations. Also, broadleaf evergreen species have been reported to be more resistant to $\mathrm{O}_{3}$ than broadleaf deciduous species (Calatayud et al., 2010, 2011; Zhang et al., 2012). However, a study by Reich (1987) suggested that when taking into account $\mathrm{O}_{3}$ uptake (or flux) per leaf life span, conifers and hardwoods have similar sensitivity in terms of declines in photosynthesis and growth. This analysis provided an opportunity to investigate these issues in further detail using more advanced methods for estimating stomatal $\mathrm{O}_{3}$ flux.

The overall aim of this study was to evaluate the performance of PODy and AOT40 metrics in predicting biomass reductions for forest trees. This was achieved through analysis of the statistical performance of linear regressions of DRR constructed using data collected from fumigation and filtration studies. This work was conducted with a view to developing new DRR that could be used in the derivation of critical levels within the LRTAP Convention.

\section{Materials and methods}

\subsection{Estimating stomatal conductance gs}

The stomatal conductance $\left(\mathrm{g}_{\mathrm{s}}\right)$ algorithm of the $\mathrm{DO}_{3} \mathrm{SE}$ (Deposition of $\mathrm{O}_{3}$ for stomatal exchange) model was used as the basis for estimates of $g_{s}$ for all model runs. The model employs a multiplicative algorithm, based on that first developed by Jarvis (Jarvis, 1976), modified for $\mathrm{O}_{3}$ flux estimates (Emberson et al., 2000a, 2000b, 2001, 2007; Büker et al., 2012) to estimate leaf/needle $g_{s}$ (the inverse of $\mathrm{r}_{\mathrm{s}}$ (stomatal resistance)) as:

$g_{s}=g_{\text {max }} * f_{\text {phen }} * f_{P P F D} * \max \left\{f_{\min }, f_{T} * f_{D} * f_{S W}\right\}$

where the species-specific maximum $g_{s}\left(g_{\max }\right)$ is modified by relative response functions (scaled from 0 to 1 ) to account for $g_{s}$ variation with leaf/needle age over the course of the growing season $\left(f_{\text {phen }}\right)$ and the functions $f_{P P F D}, f_{T}, f_{D}$ and $f_{S W}$ relating $g_{s}$ to irradiance (described as photosynthetic photon flux density, PPFD, $\mu \mathrm{mol} / \mathrm{m}^{2} / \mathrm{s}$ ), temperature ( $T$, degrees Celcius), vapour pressure deficit of the air $(D, \mathrm{kPa})$ and soil water, respectively. $f_{S W}$ can either be related to soil water potential (SWP in MPa) or plant available soil water expressed in volumetric terms (PAW in \% vol $/ \mathrm{vol}) . f_{\min }$ is the minimum daylight $g_{s}$ under field conditions, expressed as a fraction of $g_{\max }$. 


\subsection{Estimating gs for 'real' species modelling}

The parameters and functions used for the estimation of 'real' species $g_{s}$ are those defined in the mapping manual of the Convention on Long-Range Transboundary Air Pollution (LRTAP) (LRTAP Convention, 2010) with the exception of i. $g_{\max }$ values which have been revised according to newly available datasets since the publication of Karlsson et al. (2007) (i.e. LRTAP Convention, 2010; Marzuoli et al., 2009) and a recently modified diffusivity ratio of $\mathrm{O}_{3}$ to water vapour of 0.663 (Grünhage et al., 2012); ii. a phenology function which is defined either by latitude according to LRTAP Convention (2010) or by information provided by holders of the experimental data included in this study (see Section 2.5 and Table 1 and Table S1 for further details) and; iii. the parameterisation for poplar, which was taken from Marzuoli et al. (2009) since a parameterisation for this species was previously not defined. All parameterisations used here are described in Table 1.

\subsection{Estimating gs using a simplified parameterisation}

A second set of model runs was based on a simplified parameterisation of the model to test the feasibility of using less parameter-intensive estimates of environmental influences on $g_{s}$ for tree species and groups of species. This simple model kept the same $f_{S W}$ and $f_{\text {phen }}$ formulation and parameterisation as described in Table 1 . However, the formulations for $f_{P P F D}, f_{T}$ and $f_{D}$ have been revised with the intention to develop standard functions that can be used for all tree species. This simplified formulation of the flux model represents a new development of the "generic" tree modelling concept presented in LRTAP Convention (2010), and
Table 2

Temperature parameterisation for all sites, irrespective of species that were exposed to $\mathrm{O}_{3}$ there. For detailed information on sites, see Table 3 .

\begin{tabular}{lcll}
\hline Site & $\mathrm{T}_{\min }\left({ }^{\circ} \mathrm{C}\right)$ & $\mathrm{T}_{\text {opt }}\left({ }^{\circ} \mathrm{C}\right)$ & $\mathrm{T}_{\max }\left({ }^{\circ} \mathrm{C}\right)$ \\
\hline Birmensdorf & 9 & 21 & 45 \\
Kuopio & 3 & 16 & 45 \\
Östad & 1 & 17 & 45 \\
Schönenbuch & 7 & 20 & 45 \\
Zugerberg & 5 & 18 & 45 \\
Col du Donon & -1 & 13 & 45 \\
Ebro delta & 12 & 25 & 45 \\
Headley & 6 & 20 & 45 \\
Curno & 10 & 24 & 45 \\
Grignon & 7 & 17 & 45 \\
\hline
\end{tabular}

includes for the first time flux based DRR. These functions, described by a single formulation, are detailed in the following equations.

$f_{P P F D}=f_{\text {min }}+0.9 *\left(1-\operatorname{EXP}\left(\right.\right.$ light $\left.\left._{-} a^{*} P P F D\right)\right)$

where $f_{P P F D}$ follows a rectangular hyperbola and light_a is 0.006 ; the structure of the formula is such that $f_{\min }$ also operates during the night-time period. This parameterisation has proved reasonable for the two most common species in the present dataset, birch (Uddling et al., 2004, 2005) and Norway spruce (Tarvainen et al., 2013), and the assumption is made that other species will follow a similar $f_{\text {PPFD. }}$.

$f_{D}=\min (1,1-0.6 * \ln (D))$

Table 1

Parameterisation of $\mathrm{DO}_{3} \mathrm{SE}$ model for forest trees.

\begin{tabular}{|c|c|c|c|c|c|c|c|c|c|c|}
\hline Parameter & Units & Beech & Birch & $\begin{array}{l}\text { Temperate } \\
\text { oak }\end{array}$ & $\begin{array}{l}\text { Norway } \\
\text { spruce }\end{array}$ & $\begin{array}{l}\text { Norway } \\
\text { spruce }\end{array}$ & Holm oak & $\begin{array}{l}\text { Aleppo } \\
\text { pine }\end{array}$ & $\begin{array}{l}\text { Scots } \\
\text { pine }\end{array}$ & Poplar \\
\hline Region $^{f}$ & & CCE & $\mathrm{NE}$ & ACE & NE & CCE & $\mathrm{ME}$ & ME & ACE & c \\
\hline$g_{\max }$ & $\begin{array}{l}\mathrm{mmol} \mathrm{O}_{3} \mathrm{~m}^{-2} \\
\mathrm{PLA} \mathrm{s}^{-1}\end{array}$ & 150 & 240 & 255 & 125 & 130 & 195 & 230 & 190 & $575 / 540$ \\
\hline $\mathrm{f}_{\min }$ & fraction & 0.13 & 0.1 & 0.06 & 0.1 & 0.16 & 0.02 & 0.15 & 0.1 & 0.1 \\
\hline $\mathrm{SGS}^{\mathrm{e}}$ & year day & LF or DP & LF & LF or DP & DP & DP & $1-365$ & $1-365$ & DP & DP \\
\hline $\mathrm{EGS}^{\mathrm{e}}$ & year day & LF or DP & LF & LF or DP & DP & DP & $1-365$ & $1-365$ & DP & DP \\
\hline $\mathrm{f}_{\text {phen_lim }}^{\mathrm{A}}$ & year day & - & - & - & - & - & 80 & 80 & - & - \\
\hline $\mathrm{f}_{\text {phen_lim }}^{\mathrm{B}}$ & year day & - & - & - & - & - & 320 & 320 & - & - \\
\hline $\mathrm{f}_{\text {phen_a }}$ & fraction & 0.0 & 0.0 & 0.0 & 0.0 & 0.0 & 1.0 & 1.0 & 0.8 & 0.0 \\
\hline $\mathrm{f}_{\text {phen_b }}$ & fraction & $(1.0)$ & $(1.0)$ & $(1.0)$ & $(1.0)$ & $(1.0)$ & 1.0 & 1.0 & $(1.0)$ & $(1.0)$ \\
\hline $\mathrm{f}_{\text {phen_c }}$ & fraction & 1.0 & 1.0 & 1.0 & 1.0 & 1.0 & 0.3 & 0.1 & 1.0 & 1.0 \\
\hline $\mathrm{f}_{\text {phen_d }}$ & fraction & $(1.0)$ & $(1.0)$ & $(1.0)$ & $(1.0)$ & $(1.0)$ & 1.0 & 1.0 & $(1.0)$ & $(1.0)$ \\
\hline $\mathrm{f}_{\text {phen_e }}$ & fraction & 0.4 & 0.0 & 0.0 & 0.0 & 0.0 & 1.0 & 1.0 & 0.8 & 0.0 \\
\hline $\mathrm{f}_{\text {phen_f }}$ & days & 20 & 20 & 20 & 20 & - & 130 & 130 & 40 & 20 \\
\hline $\mathrm{f}_{\text {phen_g }}$ & days & 20 & 30 & 30 & 30 & - & 60 & 60 & 40 & 20 \\
\hline light_a & & 0.006 & 0.0042 & 0.003 & 0.006 & 0.01 & 0.012 & 0.013 & 0.006 & 0.006 \\
\hline $\mathrm{T}_{\min }$ & ${ }^{\circ} \mathrm{C}$ & 5 & 5 & $0^{\mathrm{b}}$ & 0 & 0 & 1 & 10 & 0 & 11 \\
\hline $\mathrm{T}_{\mathrm{opt}}$ & ${ }^{\circ} \mathrm{C}$ & 16 & 20 & $20^{\mathrm{b}}$ & 20 & 14 & 23 & 27 & 20 & 27 \\
\hline $\mathrm{T}_{\max }$ & ${ }^{\circ} \mathrm{C}$ & 33 & $200^{\mathrm{a}}$ & $35^{\mathrm{b}}$ & $200^{\mathrm{a}}$ & 35 & 39 & 38 & 36 & 36 \\
\hline $\mathrm{VPD}_{\max }$ & $\mathrm{kPa}$ & 1.0 & 0.5 & $1.0^{\mathrm{b}}$ & 0.8 & 0.5 & 2.2 & 1.0 & 0.6 & 2.1 \\
\hline $\mathrm{VPD}_{\min }$ & $\mathrm{kPa}$ & 3.1 & 2.7 & $3.25^{\mathrm{b}}$ & 2.8 & 3.0 & 4.0 & 3.2 & 2.8 & 3.7 \\
\hline SWP/PAW & $\begin{array}{l}\mathrm{MPa} / \% \text { vol } \\
\mathrm{vol}^{-1}\end{array}$ & $\begin{array}{l}\text { If SWP, di } \\
\text { footnote }^{d}\end{array}$ & tion betv & boreal/temp & and Medit & lean fores & species; det & f SWP a & W parar & risation in \\
\hline Leaf dimension & $\mathrm{cm}$ & 7.0 & 5.0 & 5.0 & 0.8 & 0.8 & 5.5 & 0.8 & 0.8 & 10 \\
\hline
\end{tabular}

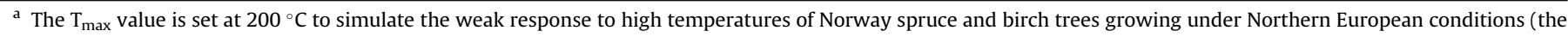
stomatal response is instead mediated by high VPD values). Hence, the $\mathrm{T}_{\max }$ value should be viewed as a forcing rather than descriptive parameter.

b "Generic" deciduous parameterisation used as surrogate.

c Parameterisation as given by Marzuoli et al. (2009) for young poplar trees, apart from $\mathrm{g}_{\max }$, which is based on site-specific measurements ( 575 mmol $\mathrm{O}_{3} \mathrm{~m}^{-2} \mathrm{PLA}$ $\mathrm{s}^{-1}=$ Curno, $540 \mathrm{mmol} \mathrm{O}_{3} \mathrm{~m}^{-2}$ PLA s${ }^{-1}=$ Grignon; italics represent values taken from beech ACE parameterisation).

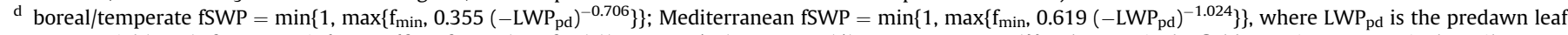

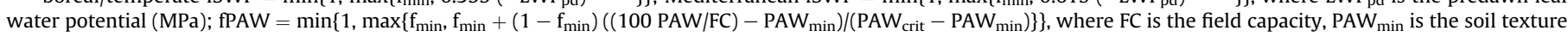

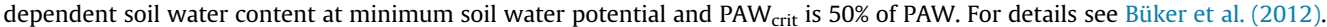

e $\mathrm{LF}=$ Latitude function according to LRTAP Convention (2010); DP = Data provided by data holders of experiments presented in Table 3 . See also Table S1.

${ }^{\mathrm{f}} \mathrm{NE}=$ Northern Europe; $\mathrm{ACE}=$ Atlantic Central Europe; $\mathrm{CCE}=$ Continental Central Europe; $\mathrm{ME}=$ Mediterranean Europe. 
This $f_{D}$ (except for its "min" formulation) is supported by the theory on tree hydraulics and has been shown to hold for a broad range of tree species (Oren et al., 1999). The commonly used bellshaped $f_{T}$ (LRTAP Convention, 2010) is given by:

$$
\begin{aligned}
f_{T}= & \max \left(f_{\min },\left(\left(T-T_{\min }\right) /\left(T_{\text {opt }}-T_{\min }\right)\right)\right. \\
& \left.*\left(\left(T_{\max }-T\right) /\left(T_{\max }-T_{\text {opt }}\right)\right)^{b t}\right)
\end{aligned}
$$

where $T_{\min }, T_{o p t}$ and $T_{\max }$ are the species-specific minimum, optimum and maximum $T$, respectively. $b t$ is defined as:

$b t=\left(\mathrm{T}_{\max }-\mathrm{T}_{\text {opt }}\right) /\left(\mathrm{T}_{\text {opt }}-\mathrm{T}_{\min }\right)$

Eq. (4) was only applied, if $T_{\min }<T \leq T_{\text {opt }}$. If $T<T_{\min }$,

$f_{T}=f_{\min }$

While traditionally $\mathrm{f}_{T}$ drops to 0 if $T_{\max }>T>T_{\text {opt }}$, here a nonlimiting $T$ effect on $\mathrm{g}_{\mathrm{s}}$ is assumed if $T_{\max }>T>T_{\text {opt }}$, i.e. the effect of $T$ on stomatal closure within this $T$ range is thus assumed to be mediated through the effect of $T$ on $D$ : If $T_{\max }>T>T_{o p t}$

$f_{T}=1$

and if $T>T_{\max }$, then

$f_{T}=0$

The $f_{T}$ parameterisation was defined by analysing the sitespecific growing season $24-\mathrm{h} T$ at each site and using the $1 \mathrm{st}$ percentile and mean temperatures as the $T_{\min }$ and $T_{o p t}$ values respectively. The growth period was defined as for the 'real' species parameterisation (Table 1 and Table S1). Hence, this parameterisation is site- rather than species-specific. $T_{\max }$ was fixed at $45{ }^{\circ} \mathrm{C}$ which is an average maximum $T$ below which the most droughtadapted European trees can maintain their physiological activity (Larcher, 2003). The simplified parameterisation of $f_{T}$ for all sites is also described in Table 2. Finally, $\mathrm{f}_{\min }$ was set to 0.1 for the simplified parameterisation.

\subsection{Estimating PODy and AOT40}

The calculation of PODy requires estimates of stomatal $\mathrm{O}_{3}$ flux $\left(F_{s t}\right)$ which are made according to the LRTAP Convention (2010). $F_{s t}$ ( $\mathrm{nmol} \mathrm{O} \mathrm{m}^{-2}$ Projected Leaf Area (PLA) $\mathrm{s}^{-1}$ ) is calculated according to Eq. (9) which accounts for deposition to the cuticle through incorporation of the leaf surface resistance $\left(r_{c}\right)$ and boundary layer resistance $\left(r_{b}\right)$ terms:

$F_{\mathrm{st}}=c\left(z_{1}\right) * g_{s} * \frac{r_{c}}{r_{b}+r_{c}}$

where $c\left(z_{1}\right)$ is the concentration of $\mathrm{O}_{3}$ at the top of the canopy (nmol m $\mathrm{m}^{-3}$ ) at height $z_{1}(\mathrm{~m}), \mathrm{g}_{\mathrm{s}}$ is in $\mathrm{m} \mathrm{s}^{-1}, r_{b}$ is the leaf quasilaminar resistance and $r_{c}$ the leaf surface resistance, both given in $\mathrm{s} \mathrm{m}{ }^{-1}$. For further details on the resistance scheme see LRTAP Convention (2010). The accumulated $F_{s t}$ above an $\mathrm{O}_{3}$ stomatal flux threshold of $y\left(\mathrm{nmol} \mathrm{m} \mathrm{m}^{-2} \mathrm{~s}^{-1}\right)$ provides the PODy index and is calculated according to Eq. (10).

$\mathrm{POD}_{y}=\sum_{i=1}^{n} \max \left[\mathrm{F}_{\mathrm{st}_{\mathrm{i}}}-y, 0\right] * \Delta t$

where $\mathrm{F}_{\mathrm{St}_{i}}$ is the stomatal $\mathrm{O}_{3}$ flux $\left(\mathrm{nmol} \mathrm{O}_{3} \mathrm{~m}^{-2} \mathrm{PLA} \mathrm{h}^{-1}\right)$ and $y$ is the threshold stomatal flux per projected leaf area (PLA) (in nmol $\left.\mathrm{O}_{3} \mathrm{~m}^{-2} \mathrm{~s}^{-1}\right)$. The calculation of PODy is based on hourly values $\left(\mathrm{F}_{\mathrm{st}_{i}}\right)$, so $\Delta t=1 \mathrm{~h} . n$ is the number of hours within the defined growth period. We trialled small $y$ increments of 0.1 from 0 to $6 \mathrm{nmol}$ $\mathrm{O}_{3} \mathrm{~m}^{-2}$ PLA s ${ }^{-1}$ to facilitate a more precise determination of the ' $y$ ' threshold.

Estimates of AOT40 (Accumulated Over a Threshold of $\mathbf{4 0} \mathrm{ppb}$ ozone) are performed using the methodology outlined in the LRTAP Convention (2010):

AOT40 $=\sum_{i=1}^{n} \max \left[c_{i}-40,0\right]^{*} \Delta t$,

Where 40 is the threshold concentration (in ppb) and the calculation of AOT40 is based on hourly values $\left(\mathrm{c}_{\mathrm{i}}\right)$ so that $\Delta t=1 \mathrm{~h}$ and $n$ is again the number of hours within the defined growth period.

The model runs were performed using the interfaced version of $\mathrm{DO}_{3} \mathrm{SE}$ (http://www.sei-international.org/do3se). This code has been rigorously tested and provides a definitive set of algorithms that represent the current formulations and parameterisations to derive PODy (LRTAP Convention, 2010) as well as AOT40 values.

\subsection{Description of sites and datasets}

This study used $\mathrm{O}_{3}$ experimental fumigation or filtration datasets collected for eight different species: birch (Betula pendula), beech (Fagus sylvatica), temperate oak (Quercus robur or petraea), Norway spruce (Picea abies), Scots pine (Pinus sylvestris), Aleppo pine (Pinus halepensis), Holm oak (Quercus ilex) and poplar hybrids (Populus maximowicz $\times$ Populus berolinensis or Populus deltoides $\times$ Populus nigra). These datasets were from ten different sites in seven countries (Sweden, Finland, U.K., France, Switzerland, Spain and Italy), thereby representing all major European climatic zones defined in the UNECE Mapping Manual (LRTAP Convention, 2010). Six experiments from France, Italy, Spain and Sweden contained reduced water supply treatments created either by i. reduced irrigation for up to 10 weeks, ii. reduced precipitation (with the help of an Open Top Chamber (OTC) roof) for up to 20 weeks or iii. no irrigation but full precipitation for the entire growing season. Further details of these treatments by dataset are provided in Table 3.

One of the datasets that had been included in the earlier study by Karlsson et al. (2007) is excluded from this study due to too few replicates having been conducted in the experiment. This study also includes three new datasets for Holm oak and poplar collected from sites in France, Italy and Spain (Table 3).

Apart from two open-field systems in Grignon (Le Thiec, pers. comm.; Ahmad et al., 2012) and Kuopio (Oksanen, 2003), all other sites were equipped with Open Top Chambers (OTC) for the exposure of young trees to $\mathrm{O}_{3}$. Details about the individual experiments can be found in Table 3 and the papers referenced therein. The control treatment in these experiments was either charcoal-filtered or ambient (non-filtered) air, and the $\mathrm{O}_{3}$ treatments were ambient air, charcoal filtered plus additional $\mathrm{O}_{3}$ or ambient air plus additional $\mathrm{O}_{3}$. The response parameter used for the derivation of the DRR was wherever possible total biomass; where root biomass was not available, above-ground biomass was used.

In LRTAP Convention (2010), the growing season is estimated using the latitude model for forests that do not have a year-round growth habit. However, the experiments included in this analysis were predominantly performed in OTCs and the fumigation or filtration periods were sometimes outside of the latitude functionderived growth period. Hence, only experiments that captured $60 \%$ or more of this period were included here to ensure that $\mathrm{O}_{3}$ exposures covered the majority of the estimated growing season. Table $\mathrm{S} 1$ gives the $\mathrm{O}_{3}$ flux accumulation period, as defined by the 
fumigation or filtration period.

The calculation of PODy required that the practitioner of each experimental site provided a full complement of hourly meteorological data from which $T, D$ and PPFD could be determined according to standard methods (Jones, 1992). Hourly canopy height $\mathrm{O}_{3}$ concentration data as well as a seasonal profile of soil water status was also required.

\subsection{Derivation of $\mathrm{O}_{3}$ flux based dose-response relationships}

The PODy and AOT40 were accumulated over the entire length of each individual growing season of each experiment. When experiments covered multiple growing seasons, the PODy and AOT40 of the fumigation periods of all growing seasons were summed and then divided by the number of growing seasons to obtain the mean annual PODy and AOT40.

In order to standardise the biomass response data from experiments of differing duration, the following formula (Fuhrer, 1994) was applied to calculate the mean annual percentage reduction in biomass relative to the control $\left(\mathrm{RB}_{\text {annual }}\right)$ :

$\mathrm{RB}_{\text {annual }}=100 *\left(\mathrm{~B}_{\text {treat }} / \mathrm{B}_{\text {control }}\right)^{(1 / \mathrm{n})}$

where $\mathrm{B}_{\text {treat }}$ and $\mathrm{B}_{\text {control }}$ represent the biomass at ambient or elevated $\mathrm{O}_{3}$ exposures and a control at zero AOT40 or PODy respectively, and $\mathrm{n}$ is the number of growing seasons. This equation assumes a constant ozone-induced percentage reduction in biomass accumulation across years in multi-year experiments.

For experiments that used non-filtered ambient air (NF) rather than CF as control treatment or that had a PODy or AOT40 of greater than 0 for the $\mathrm{CF}$ treatment, the biomass of the control was recalculated as the Y-intercept value resulting from the linear regression of biomass (Y-axis) and $\mathrm{O}_{3}$ exposure (X-axis) data (Fuhrer, 1994). The reduction in biomass for each treatment was calculated relative to the hypothetical biomass at zero AOT40 or zero PODy, which enabled the comparison of experiments that had either $\mathrm{CF}$ or NF control treatments. Species were investigated either as single or groups of species. Broader species groupings allowed analysis of responses according to plant functional types, with needleleaf trees (Picea abies, Pinus halepensis and Pinus sylvestris) and broadleaf deciduous trees (Betula pendula, Fagus sylvatica, Populus spec., Quercus robur and Quercus petraea) being used as comparative groupings.

For the derivation of concentration- and flux-based DRR, the relationships between $\mathrm{RB}_{\text {annual }}$ and the mean annual AOT40 or PODy were fitted using the linear regression and mixed linear regression in $\mathrm{R}$ (version 3.1.3) and covering data from all $\mathrm{O}_{3}$ treatments including the control, without forcing the regression through 1 on the Y-axis. Each data point included in the regression analysis represented a single value for each species, treatment and harvest of each experiment. The $R^{2}$ and confidence intervals (C.I.) of the slope of the regression line were used to test the robustness of DRR.

For the linear regression and mixed linear regression the function gls and lme were used, respectively (package nlme; Pinheiro et al., 2015). A correction for heteroscedasticity was made using the option weights $=\operatorname{varPower}()$. The Akaike Information Criteria (AIC) was used to decide which regression type was appropriate. In most cases the simple regression with heteroscedasticity correction yielded the lowest AIC (and hence the strongest regression), except for the groups "needleleaf trees" and "Quercus ilex and P. halepensis", where the inclusion of species as cluster improved the AIC. The ' $y$ ' thresholds of the PODy indices that yield intercept C.I. that include $100 \%$ can be deemed to provide statistically robust DRR.

However, it is also useful to set some objective criteria by which a clear indication of the relative performance of different ' $y$ ' (nmol m${ }^{-2} \mathrm{~s}^{-1}$ ) thresholds can be assessed when comparing between species and PFTs. This was achieved by analysing key attributes of the (mixed) linear regressions between PODy and biomass reduction, namely the Y-axis intercept and its C.I. and $R^{2}$ values of each dose-response regression with incrementally increasing ' $y$ ' thresholds. These attributes used two criteria: a) that the C.I. of the intercept includes $100 \%$ and $b$ ) that the $\mathrm{R}^{2}$ value is within $2 \%$ of the maximum $R^{2}$ value.

Table 3

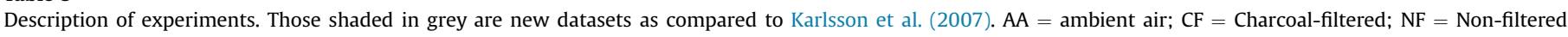
(ambient); $\mathrm{CF} / \mathrm{NF}+/++=$ Charcoal-filtered or Non-filtered plus addition of $\mathrm{O}_{3}$. OTC $=$ Open top chamber.

\begin{tabular}{|c|c|c|c|c|c|c|c|c|c|}
\hline Species & Site & $\begin{array}{l}\text { Exposure } \\
\text { system }\end{array}$ & $\begin{array}{l}\text { Control } \\
\text { treatment }\end{array}$ & $\begin{array}{l}\text { Ozone } \\
\text { treatments }\end{array}$ & $\begin{array}{l}\text { Experiment } \\
\text { duration } \\
\text { (yrs) }\end{array}$ & $\begin{array}{l}\text { Red. } \mathrm{H}_{2} \mathrm{O} \\
\text { treatment }\end{array}$ & $\begin{array}{l}\text { Tree age at } \\
\text { start of } \\
\text { experiment } \\
\text { (yrs) }\end{array}$ & Response parameter & Reference \\
\hline \multirow[t]{3}{*}{ Betula pendula } & Birmensdorf $(\mathrm{CH})$ & OTC & $\mathrm{CF}$ & $\begin{array}{l}\mathrm{CF}+, \mathrm{CF}++ \\
\mathrm{CF}+++\end{array}$ & 1 & No & Cuttings & Total biomass & Uddling et al. (2004) \\
\hline & Kuopio (FIN) & Open-field & AA & $\mathrm{AA}+$ & $2,2,5$ & No & 1 & Perennial biomass & Oksanen (2003) \\
\hline & Östad (S) & OTC & NF & $\mathrm{NF}+, \mathrm{NF}++$ & 1,2 & No & $<1$ & Perennial biomass & Karlsson et al. (2003) \\
\hline \multirow[t]{2}{*}{ Fagus sylvatica } & Schönenbuch (CH) & OTC & $\mathrm{CF}$ & NF & 2 & No & $<1$ & Total biomass & Braun and Flückiger (1995) \\
\hline & Zugerberg $(\mathrm{CH})$ & OTC & $\mathrm{CF}$ & NF & 2,3 & No & $<1$ & Total biomass & Braun and Flückiger (1995) \\
\hline \multirow[t]{3}{*}{ Picea abies } & Östad (S) & OTC & $\mathrm{CF}$ & $\mathrm{NF}, \mathrm{NF}+$ & $1,2,3,4$ & Yes & 3 & Total biomass & $\begin{array}{l}\text { Ottosson et al. (2003), } \\
\text { Karlsson et al. (2004) }\end{array}$ \\
\hline & Schönenbuch (CH) & OTC & $\mathrm{CF}$ & NF & 2 & No & $<1$ & Total biomass & Braun and Flückiger (1995) \\
\hline & Zugerberg $(\mathrm{CH})$ & OTC & $\mathrm{CF}$ & NF & $1,2,3$ & No & $<1$ & Total biomass & Braun and Flückiger (1995) \\
\hline Pinus halepensis & Ebro Delta (SP) & OTC & $\mathrm{CF}$ & $\mathrm{NF}, \mathrm{NF}+$ & 3 & Yes & 2 & Total biomass & $\begin{array}{l}\text { Alonso et al. (2003), } \\
\text { Elvira et al. (2007) }\end{array}$ \\
\hline Pinus sylvestris & Headley (U.K.) & OTC & NF & $\mathrm{NF}+$ & 2 & No & 1 & Above-ground biomass & Medlyn et al. (1999) \\
\hline \multirow[t]{2}{*}{ Populus spec. ${ }^{a}$} & Curno (I) & OTC & $\mathrm{CF}$ & NF & 1 & Yes & $1-2$ & Above-ground biomass & $\begin{array}{l}\text { Marzuoli et al. (2009), } \\
\text { Pollastrini et al. (2010) }\end{array}$ \\
\hline & Grignon (F) & Open-field & NF & $\mathrm{NF}+, \mathrm{NF}++$ & 1 & No & $\leq 1$ & Above-ground biomass & $\begin{array}{l}\text { Le Thiec, pers. comm., } \\
\text { Ahmad et al. (2012) }\end{array}$ \\
\hline Quercus ilex & Ebro Delta (SP) & OTC & $\mathrm{CF}$ & $\mathrm{NF}, \mathrm{NF}+$ & 2 & Yes & 2 & Above-ground biomass & Alonso et al. (2014) \\
\hline Quercus robur & Col-du-Donon (F) & OTC & $\mathrm{CF}$ & $\mathrm{NF}, \mathrm{NF}+$ & 2 & Yes & 2 & Total biomass & Dixon et al. (1998) \\
\hline or petraea & Headley (U.K.) & OTC & NF & $\mathrm{NF}+$ & 2 & No & 1 & Above-ground biomass & Medlyn et al. (1999) \\
\hline
\end{tabular}

${ }^{a}$ Either Populus maximowicz $\times$ Populus berolinensis (Curno) or Populus deltoides $\times$ Populus nigra (Grignon). 
Picea abies

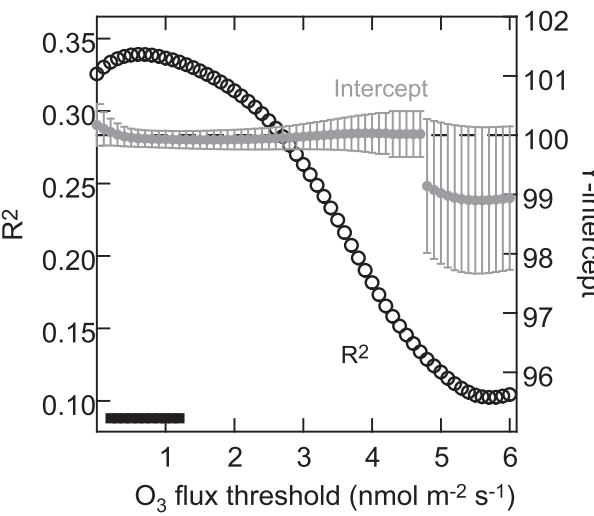

Quercus ilex \& Pinus halepensis

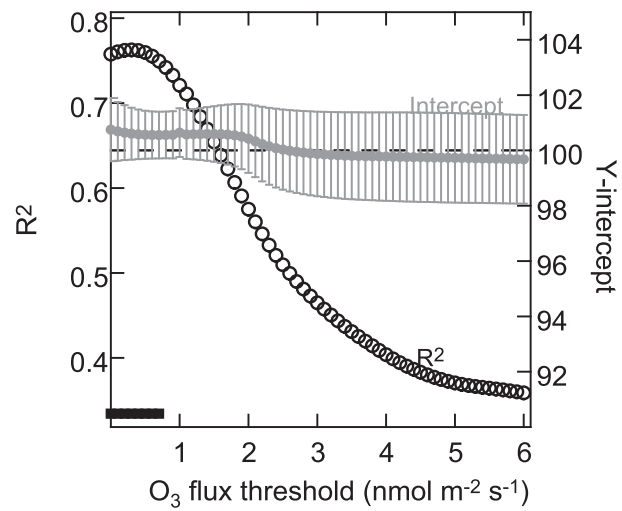

needle-leaf trees

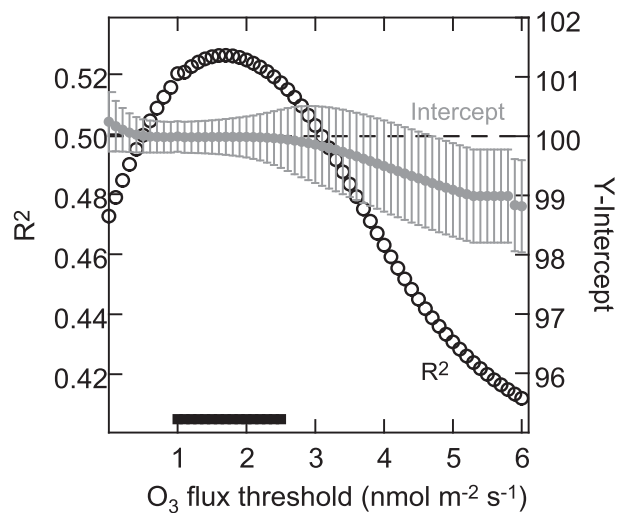

Betula pendula \& Fagus sylvatica

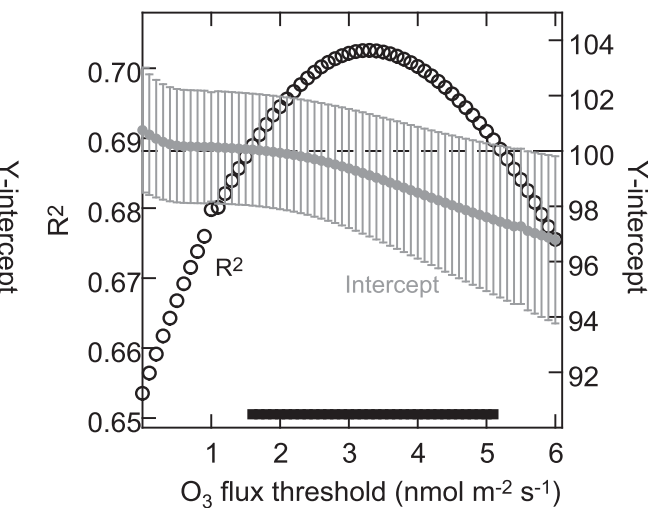

Broad-leaf deciduous trees

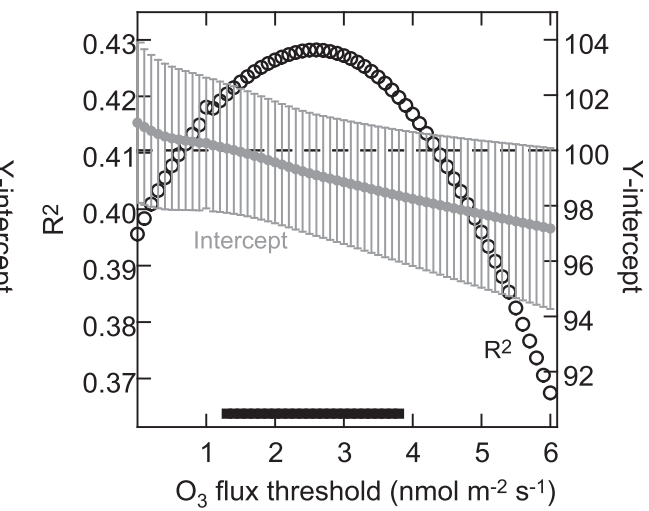

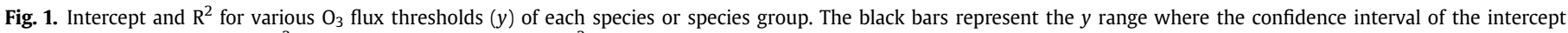
includes $100 \%$ and where the $\mathrm{R}^{2}$ is within $2 \%$ of the maximum $\mathrm{R}^{2}$.

Table 4

Overview of ' $y$ '-range for species and species-groups according to criteria defined in Section 2.6.

\begin{tabular}{lc}
\hline Species/Species-group & ' $y$ '-range \\
\hline Picea abies & $0.2-1.2$ \\
Fagus sylvatica \& Betula pendula & $1.6-5.1$ \\
Quercus ilex \& Pinus halepensis & $0.0-0.7$ \\
Broadleaf deciduous trees & $1.3-3.8$ \\
Needleleaf trees & $0.9-2.5$ \\
\hline
\end{tabular}

\section{Results}

\subsection{Derivation of $y$ threshold}

The $y$ range according to the criteria outlined in Section 2.6 is largest for beech/birch and broadleaf deciduous trees, and smallest for Holm oak and Aleppo pine (black bars in Fig. 1; Table 4). The confidence intervals of the intercept were smaller for needleleaf as compared of broadleaf trees. The maximum $\mathrm{R}^{2}$ was highest for Holm oak and Aleppo pine and smallest for Norway spruce (Fig. 1; 
Picea abies

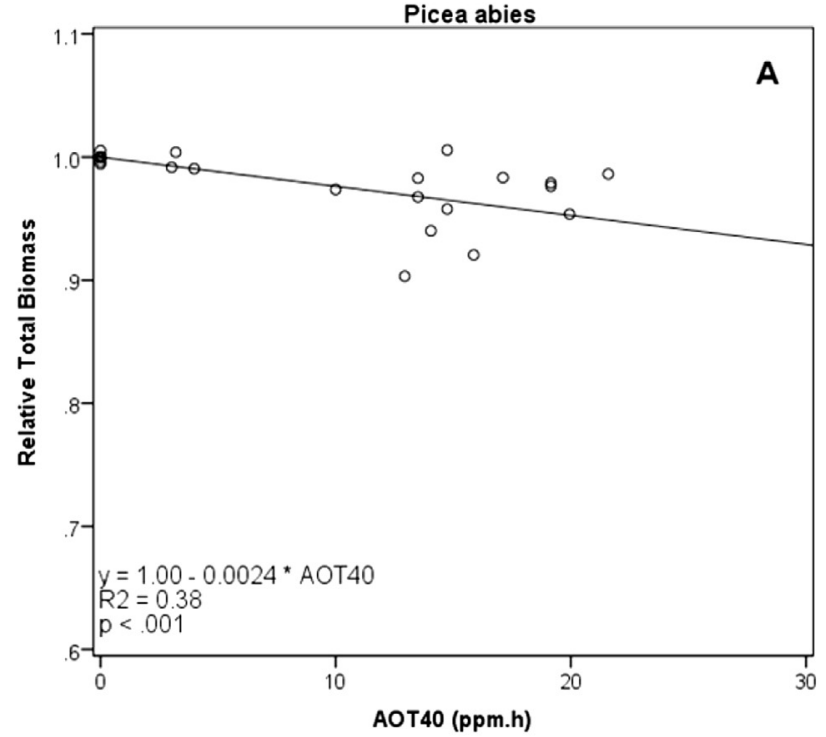

Picea abies - standard model

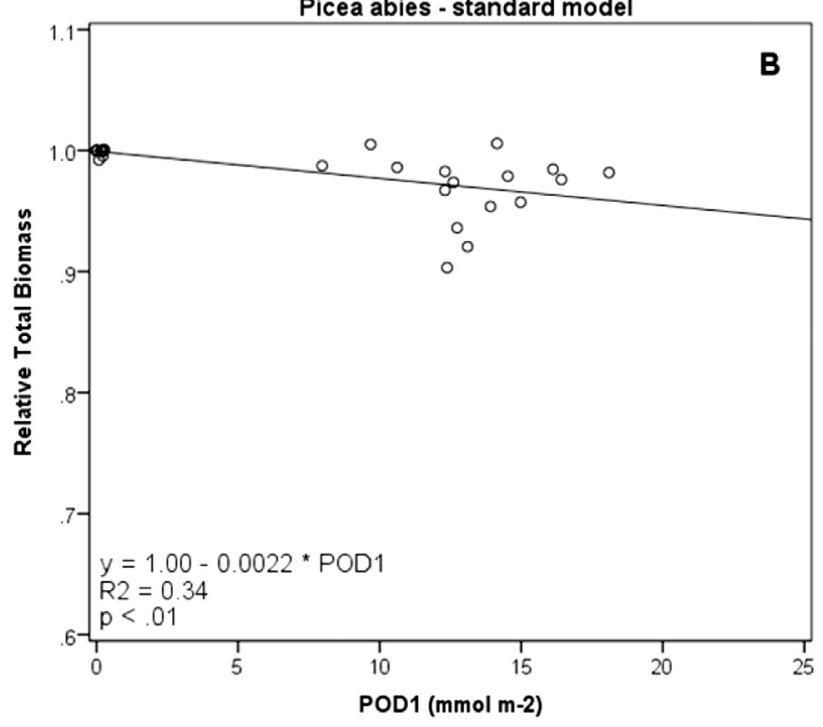

Picea abies - simple model

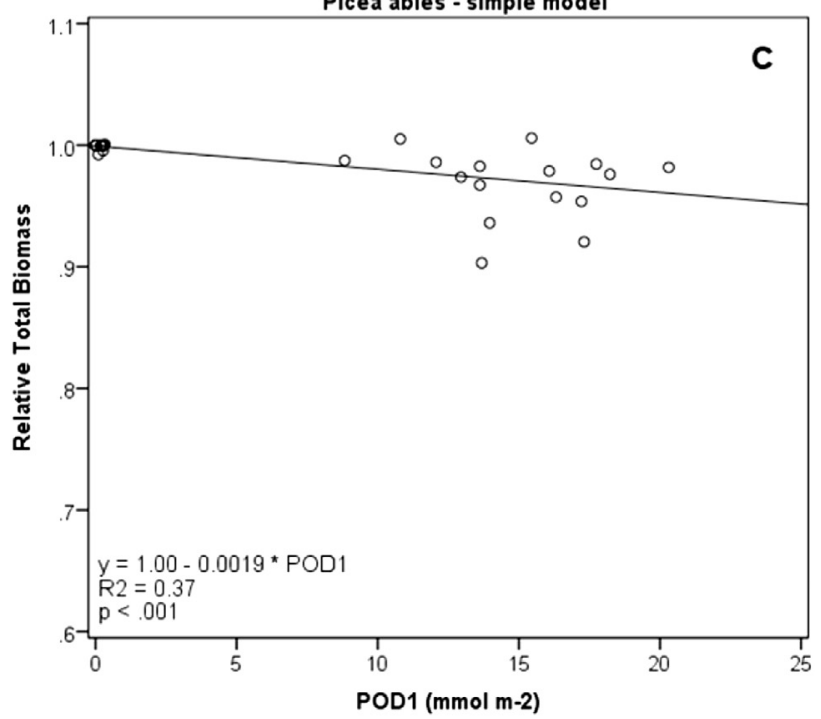

Fig. 2. Dose-response relationships for Picea abies for $\mathrm{O}_{3}$ indices $\mathrm{A}$ ) AOT40, B) standard "real species" model $\mathrm{POD}_{1}$ and $\mathrm{C}$ ) simplified model $\mathrm{POD}_{1}$.
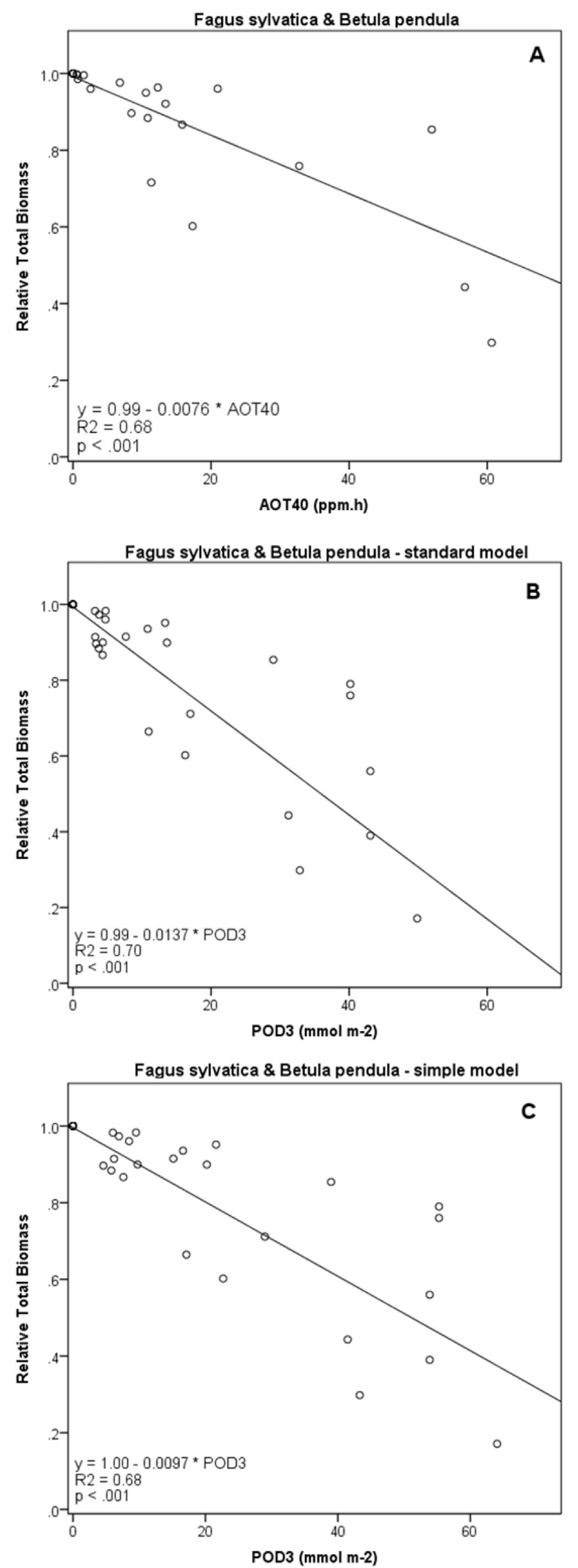

Fig. 3. Dose-response relationships for Fagus sylvativa and Betula pendula for $\mathrm{O}_{3}$ indices A) AOT40, B) standard "real species" model $\mathrm{POD}_{3}$ and C) simple model $\mathrm{POD}_{3}$. 

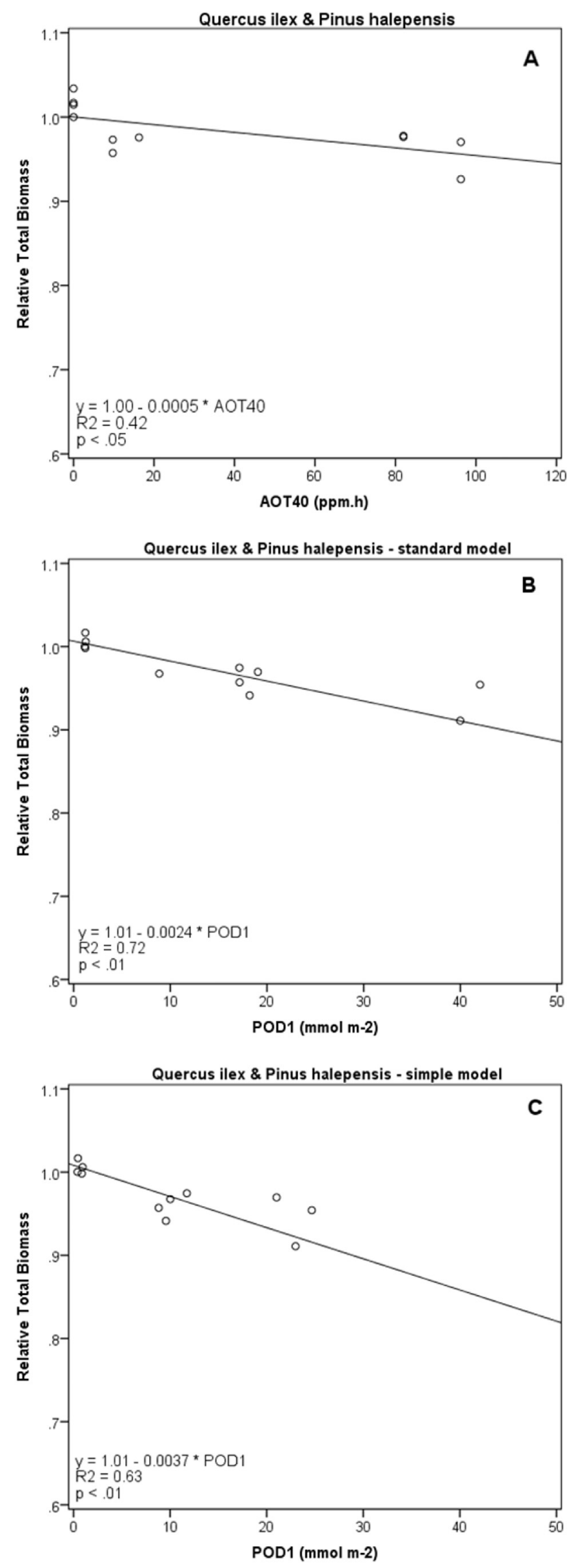

NB: The displacement of the intercept (and its C.I.) of Norway spruce is due to one value dominating the intercept above $y=4.7 \mathrm{nmol} \mathrm{m}^{-2} \mathrm{~s}^{-1}$ ).

For the following definition of DRR, exemplary ' $y$ ' thresholds (rounded to the next natural number) closest to the maximum $\mathrm{R}^{2}$ of each species and species group were chosen.

\subsection{Dose-response relationships}

For Picea abies (Fig. 2), the flux based DRR using the simple model is on a par with the AOT40 based DRR $\left(R^{2}=0.37\right.$ and 0.38 ; intercept $=1.0$ and 1.0 ; slope $=-0.0019$ and -0.0024 , respectively; for standard errors (S.E.) and confidence intervals (C.I.), see Tables S2 and S7), while the flux based DRR using the standard "real-species" model is slightly less strong $\left(\mathrm{R}^{2}=0.34\right.$; intercept $=1.0$; slope $=-0.0022$; for S.E. and C.I., see Table S2).

The DRR for Betula pendula and Fagus sylvativa (Fig. 3) based on the flux based index $\mathrm{POD}_{3}$ with both $\mathrm{g}_{\mathrm{s}}$ model parameterisations $\left(\mathrm{R}^{2}=0.70\right.$ and 0.68 ; intercept $=0.99$ and 1.00 ; slope $=-0.0137$ and -0.0097 for the "real-species" and simple model, respectively; for S.E. and C.I., see Table S3) and the concentration-based index AOT40 $\left(R^{2}=0.68\right.$; intercept $=0.99$; slope $=-0.0076$; for S.E. and C.I., see Table S7) perform equally well.

For the Mediterranean evergreen species Quercus ilex and Pinus halepensis (Fig. 4), both the $\mathrm{POD}_{1}$ response relationships using the "real species" and simple model $\left(\mathrm{R}^{2}=0.72\right.$ and 0.63; intercept $=1.01$ and 1.01 ; slope $=-0.0024$ and -0.0037 , respectively; for S.E. and C.I., see Table S4) clearly outperform the AOT40based DRR $\left(R^{2}=0.42\right.$; intercept $=1.00$; slope $=-0.0005$; for S.E. and C.I., see Table S7).

Fig. 5 shows the stronger flux-based DRR $\left(R^{2}=0.52\right.$ and 0.45 ; intercept $=1.00$ and 1.00 ; slope $=-0.0042$ and -0.0038 for the "real species" and simple model, respectively; for S.E. and C.I., see Table S5) as compared to the AOT40-based DRR $\left(\mathrm{R}^{2}=0.38\right.$; intercept $=1.00$; slope $=-0.0021$; for S.E. and C.I., see Table S7) for three needleleaf tree species. The performance of all needleleaf tree DRR is better than the separate respective DRR for Picea abies alone (Fig. 2).

Fig. 6 compares the $\mathrm{POD}_{3}$-response relationships for five broadleaf deciduous tree species using the "real-species" and simple model with the AOT40-response relationship. While the differences in the $\mathrm{R}^{2}$ are fairly small $(0.41,0.38$ and 0.34 for AOT40, "real species" and simple model, respectively), the slopes differ much more $(-0.0061,-0.0098,-0.0082$ for AOT40, "real species" and simple model, respectively; for S.E. and C.I., see Tables S6 and S7). The performance of all broadleaf deciduous tree DRR is worse than the separate respective DRR for the two broadleaf species B. pendula and Fagus sylvatica (Fig. 3).

The Tables S2 to S7 provide an overview of all AOT40-and fluxbased DRR.

\subsection{Effect of reduced water supply}

Datasets of six experiments using five different species (Picea abies, P. halepensis, Quercus robur, Q. ilex and Populus spec.) comprised data points representing both well-watered and reduced-water conditions. The data points of the reduced water supply treatments are positioned within the general data cloud of Figs. 2 and 4-6 (not indicated in these figures), which suggests that they do not represent clearly distinguishable $\mathrm{O}_{3}$-uptake or

Fig. 4. Dose-response relationships for Mediterranean evergreen species Quercus ilex and Pinus halepensis for $\mathrm{O}_{3}$ indices A) AOT40, B) standard "real species" model $\mathrm{POD}_{1}$ and C) simple model $\mathrm{POD}_{1}$. 

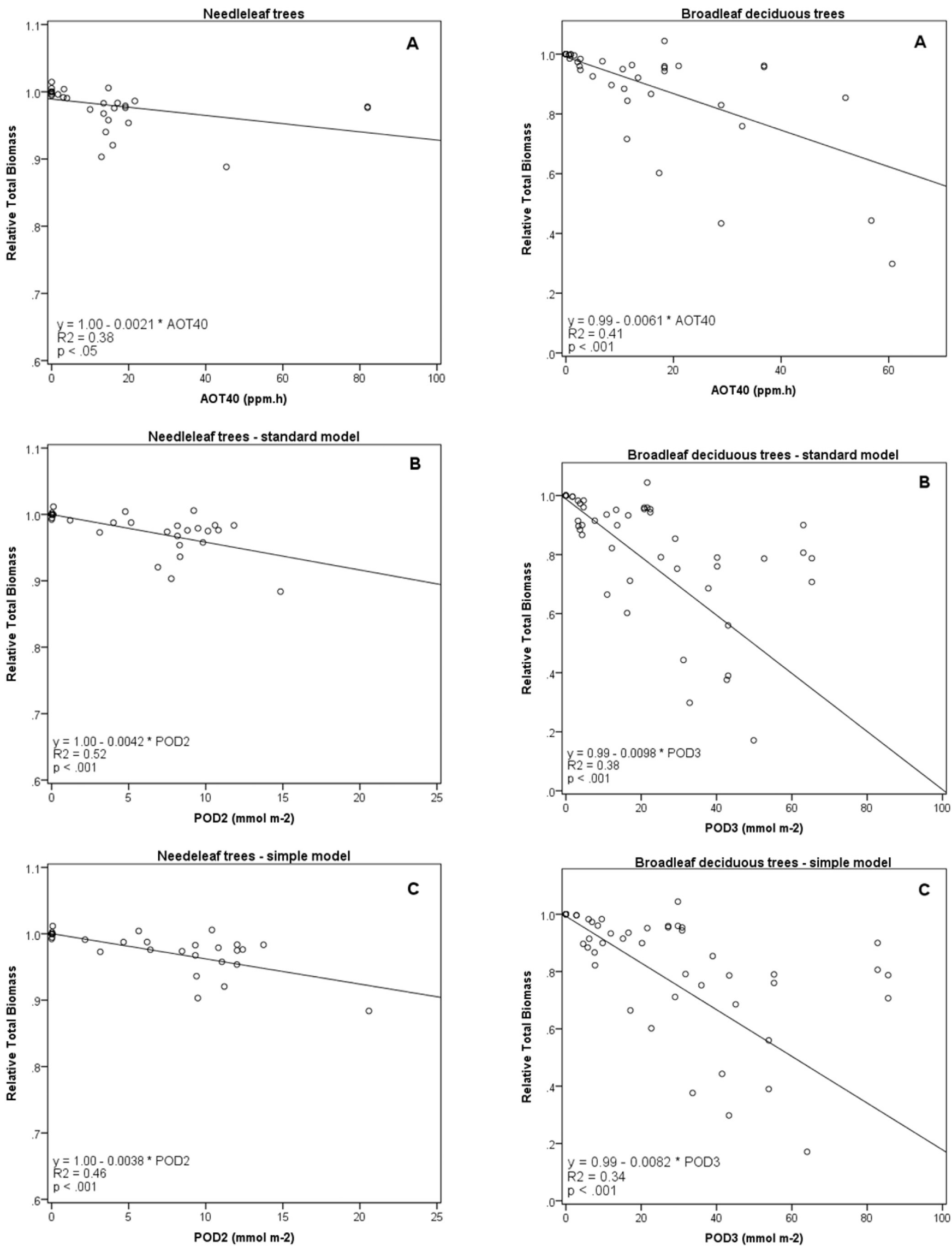

Fig. 5. Dose-response relationships for needleleaf tree species for A) AOT40, B) standard "real species model" $\mathrm{POD}_{2}$ and $\mathrm{C}$ ) simple model $\mathrm{POD}_{2}$.

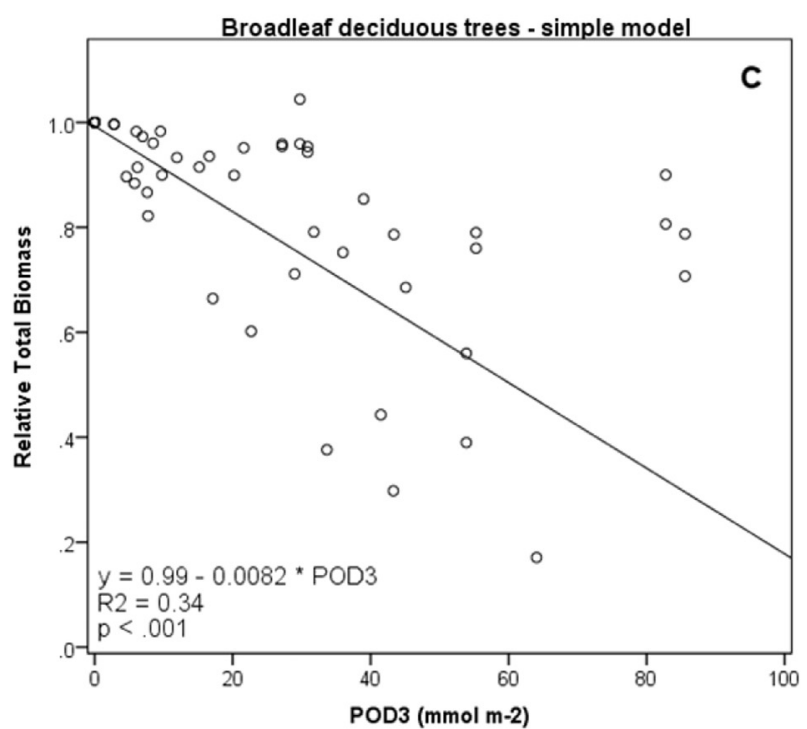

Fig. 6. Dose-response relationships for broadleaf deciduous tree species for A) AOT40, B) standard "real species model" $\mathrm{POD}_{3}$ and $\mathrm{C}$ ) simplified parameterisation $\mathrm{POD}_{3}$. 
-response conditions as compared to the well-watered treatments.

To more clearly observe the size of the effect of reduced water supply on $\mathrm{g}_{\mathrm{s}}$ and consequently on PODy, the experimental datasets that included a water stress treatment ( 15 data points in total) were directly compared with the well-water treatments of the same experiments using the "real species" model. These two sets of PODy data were plotted against each other so that the deviation from the $1: 1$ line indicated the effect of water stress on PODy (Fig. 7).

There was a significant (at 95\% confidence level) but small (9\%) deviation from the $1: 1$ line, suggesting that the effect of reduced water availability on $\mathrm{g}_{\mathrm{s}}$ and hence $\mathrm{O}_{3}$ flux was small in the experiments included in this study.

\section{Discussion}

We analysed data from 24 European field experiments to derive $\mathrm{O}_{3}$ flux based DRR for Norway spruce, beech and birch, Holm oak and Aleppo pine, as well as the two PFTs of broadleaf deciduous trees and needleleaf trees.

The inclusion of Holm oak and Aleppo pine datasets for the first time enabled the derivation of a combined DRR for Mediterranean trees only (a separate DRR for Holm oak was recently published by Alonso et al. (2014)). Despite these two species representing different PFTs, their grouping is justified due to both of them being evergreen, physiologically active throughout the year and able to cope well with Mediterranean climatic conditions, including drought. However, it should be noted that broadleaf deciduous species are also common in the Mediterranean and that these species have been shown to be more sensitive to $\mathrm{O}_{3}$ than the broadleaf evergreen species Holm oak used in this study (Calatayud et al., 2011).

Rather than suggesting species- or PFT-specific "suitable" ' $y$ ' thresholds, we give a range of different species- or PFT-specific ' $y$ ' thresholds according to statistical criteria outlined in Section 2.6. Firstly, this study shows that all of the ' $y$ ' thresholds (from 0 to 6) provide statistically robust DRR for all species and PFTs when considering the intercept CIs, with the exception of ' $y$ ' thresholds

\section{Well-watered vs. reduced-water PODy}

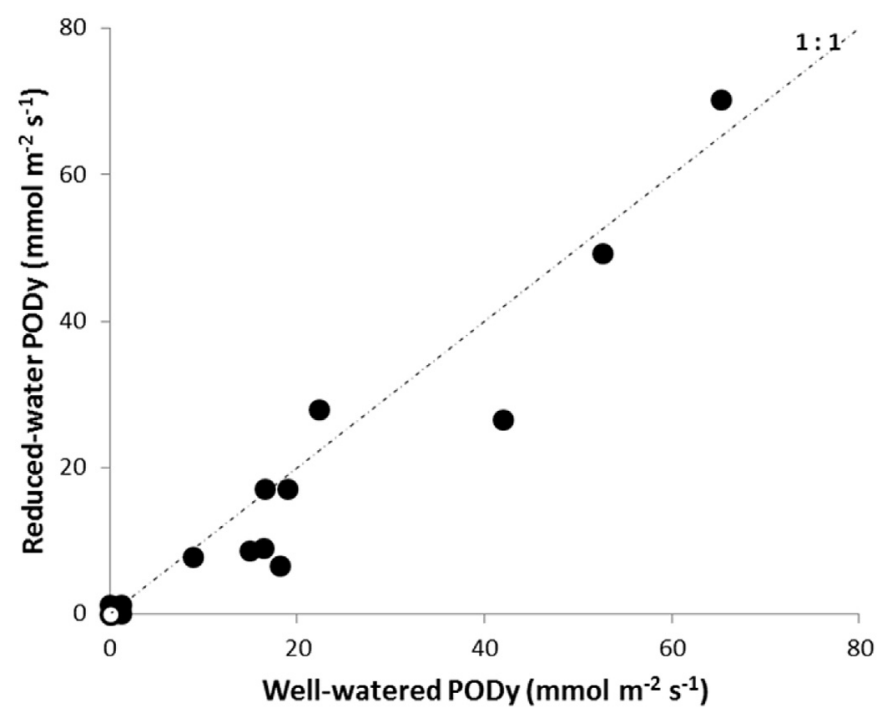

Fig. 7. Regression for PODy of well-watered vs. reduced-water treatments for five experiments representing the following trees species: Picea abies, Pinus halepensis, Quercus robur, Quercus ilex and Populus spec. The 1:1 line (dashed) is also shown. N.B. Reduced-water represents instances when $\mathrm{g}_{\mathrm{s}}$ was limited by soil water availability according to the $\mathrm{DO}_{3} \mathrm{SE}$ model (Büker et al. (2012). above $4.7 \mathrm{nmol} \mathrm{m} \mathrm{m}^{-2} \mathrm{~s}^{-1}$ for needleleaf trees. This study therefore supports the current ' $y$ ' thresholds used by LRTAP Convention (2010). When considering the intercept and $\mathrm{R}^{2}$ statistics in combination (to aid the objective comparison of these key statistical characteristics between species and PFTs), the study suggests that needleleaf trees may have a lower ' $y$ ' as compared to broadleaf deciduous trees, which might be an indication that the latter have a higher detoxification potential. In fact, Temmerman et al. (2002), Musselman et al. (2006) and Dizengremel et al. (2009) discuss the concept of varying detoxification potentials of trees in detail. They agree that given the biochemical processes (i.e. antioxidant capacity, turnover and transport) that are known to be involved in ozone scavenging, it is certain that plants have a capacity for detoxification and that this varies between species. However, the complexity of these biochemical processes currently makes it difficult to quantify this capacity either absolutely or in relative terms for different species or species groups.

The new flux-based DRR for Norway spruce is associated with a lower $R^{2}(0.34)$ than reported by LRTAP Convention (2010) $\left(\mathrm{R}^{2}=0.55\right)$, mainly because one dataset that had been used in these two previous studies and that was characterised by high PODy values had to be excluded due to a limited replication of experimental treatments. In addition, a new parameterisation for $g_{\max }$ and changes in the start and end of the phenological period (these changes applied to all species involved in this study) have also caused differences by increasing the maximum stomatal $\mathrm{O}_{3}$ flux and changing its accumulation period.

In contrast, the new DRR for beech/birch with $R^{2}$ values of 0.70 is an improvement over DRR reported previously $\left(R^{2}=0.64\right.$ in LRTAP Convention, 2010). This result is also supported by a recent epidemiological study (Braun et al., 2014) that also emphasised the transferability of DRR derived from young trees to mature trees.

The grouping of species into PFTs of broadleaf deciduous and needleleaf trees has led to fairly robust DRR; while the DRR for broadleaf deciduous trees was less robust than for beech and birch, the DRR for needleleaf trees was actually more robust than for the Norway spruce. The new DRR for PFTs clearly and uniformly demonstrate substantial loss in biomass with increasing $\mathrm{O}_{3}$ flux for European trees. As such, these new DRR for PFTs (plus that for Mediterranean trees) will expand the applicability of the flux based risk assessment method.

It would be desirable to use these new DRR to describe the relative sensitivities of different species and species groups. Ordinarily, this would be described by the slope of the regressions (provided for each of the ' $y$ ' threshold increments in the supplementary material in Table S2 to S6). However, this is complicated by the fact that the slope of the regression will also depend upon the ' $y$ ' threshold, with higher ' $y$ ' thresholds tending to have steeper slopes (as the index accumulates less quickly). Therefore it is not so straightforward to compare species sensitivities based on slopes alone. However, if we were to assume that all species had a ' $y$ ' threshold of 1 as suggested by LRTAP Convention (2010), we would get the following ranking in terms of sensitivity of the species groups and plant functional types (from higher to lower sensitivity): Beech/birch > Broadleaf deciduous trees $>$ Needleleaf trees $>$ Holm oak/Aleppo pine $>$ Norway spruce.

For application on a broader-scale, we tested the concept of using a simplified parameterisation to estimate PODy, by comparing flux-effect relationships derived using the "real species" parameterisation with those that were derived using the simplified parameterisation. These two approaches differed in terms of the parameterisation of their PPFD, $T$ and $D$ functions. Based on the statistical analysis of the DRR (see Tables S2 to S6), the model using the simplified parameterisation slightly outperformed the "real species" model for Norway spruce, whereas for all other 
species or PFT the opposite was the case (especially for the Mediterranean tree species). These results indicate that for Norway spruce, beech/birch, broadleaf deciduous trees and - to a lesser extent - needleleaf trees the differences in the performance between both models is not so severe that the application of the simple model would introduce a major loss in accuracy in predicting $\mathrm{O}_{3}$ fluxes. However, the same is not the case when applying the simplified parameterisation for Mediterranean tree species, where presumably significant uncertainties would be introduced as compared to the "real species" model, thereby questioning the general suitability of the simplified parameterisation of the model. As such, the less parameter-intensive use of the simplified parameterisation for large scale (e.g. pan-European) risk assessments is not yet possible. It would be useful to further assess whether the uncertainty introduced by applying the simplified parameterisation would vary significantly between European climatic zones and tree species.

The inclusion of datasets representing experiments performed under restricted water availability neither substantially improved nor worsened the DRR; the data points from restricted water experiments fell within the range of data points from well-watered experiments. This provides further support for use of flux based methods as compared to the concentration-based AOT40 approach, which cannot account for environmental impacts on $\mathrm{O}_{3}$ uptake by plants. The difference in the performance between the flux based and the AOT40-based DRR found in this study was comparable to earlier studies by Karlsson et al. (2007) and the LRTAP Convention (2010), despite the fact that the $\mathrm{DO}_{3} \mathrm{SE}$ model now has a much more sophisticated soil moisture deficit module that has been successfully validated (Büker et al., 2012). Further analysis found that the reduced water treatments applied in the various experiments did lead to significant but small reductions in modelled $\mathrm{g}_{\mathrm{s}}$, hence leading only to slight reductions in $\mathrm{O}_{3}$ flux (Fig. 7), which is in contrast to earlier - mostly Mediterranean - studies, for instance by Alonso et al. (2014), who used a local parameterisation of the flux model. The periods of reduced water availability were too short and moderate to represent severe drought conditions. However, actual Mediterranean conditions are likely to incur far greater soil water stress over longer time periods than were applied in the experimental studies investigated in this analysis, with consequent limitations on $\mathrm{g}_{\mathrm{s}}$ and hence reduced PODy. Therefore it is imperative to include the fSW function in models used to estimate PODy values. More prolonged episodes of reduced water availability would have had to be applied to significantly reduce $g_{s}$ and hence $\mathrm{O}_{3}$ fluxes, which could have led to an even more pronounced difference in the performance of the AOT40 as compared to the flux based risk assessment approach.

\section{Conclusions}

The analysis presented here derived new $\mathrm{O}_{3}$ flux based DRR for nine European forest tree species using varying statistically derived flux thresholds according to the species sensitivity to $\mathrm{O}_{3}$. Flux based DRR were mostly more robust than concentration based DRR. The study showed that it is possible to define DRR both by species as well as by plant functional types and that the use of a simplified parameterisation of the $g_{s}$ model can provide reasonable accuracy in the calculation of POD $_{\mathrm{y}}$ for non-Mediterranean tree species. The findings suggest that critical levels as published by the UNECE (LRTAP Convention, 2010) could be re-defined using the updated PODy estimates and biomass response datasets presented here. They also support the ' $y$ ' thresholds currently used in the PODy metrics but do suggest that there may be justification in considering differential ' $y$ ' thresholds for broadleaf and needleleaf species (the former having a higher ' $y$ ' threshold than the latter) based on an objective characterisation of key statistical parameters and how these compare between species and PFT groupings.

\section{Acknowledgements}

We would like to thank the UK Department for Environment, Food and Rural Affairs (Defra) (AQ0601) for their continuous financial support in developing and applying the $\mathrm{DO}_{3} \mathrm{SE}$ model as part of contract AQ0601. This research was part-funded by the European FP7-ENV-2011/282910 ECLAIRE (effects of climate change on air pollution impacts and response strategies for European ecosystems) project.

\section{Appendix A. Supplementary data}

Supplementary data related to this article can be found at http:// dx.doi.org/10.1016/j.envpol.2015.06.033.

\section{References}

Ahmad, R., Zuily-Fodil, Y., Passaquet, C., Bethenod, O., Roche, R., Repellin, A., 2012. Ozone and aging up-regulate type II metacaspase gene expression and global metacaspase activity in the leaves of field-grown maize (Zea mays L.) plants. Chemosphere 87, 789-795. http://dx.doi.org/10.1016/ j.chemosphere.2011.12.081.

Alonso, R., Elvira, S., González-Fernández, I., Calvete, H., García-Gómez, H., Bermejo, V., 2014. Drought stress does not protect Quercus ilex L. from ozone effects: results from a comparative study of two subspecies differing in ozone sensitivity. Plant Biol. 16, 375-384. http://dx.doi.org/10.1111/plb.12073.

Alonso, R., Elvira, S., Inclán, R., Bermejo, V., Castillo, F.J., Gimeno, B.S., 2003. Responses of Aleppo pine to ozone. In: Developments in Environmental Science. Elsevier, pp. 211-230.

Braun, S., Flückiger, W., 1995. Effects of ambient ozone on seedlings of Fagus sylvatica L. and Picea abies (L.) Karst. New. Phytol. 129, 33-44.

Braun, S., Schindler, C., Rihm, B., 2014. Growth losses in Swiss forests caused by ozone: epidemiological data analysis of stem increment of Fagus sylvatica L. and Picea abies Karst. Environ. Pollut. 192, 129-138. http://dx.doi.org/10.1016/ j.envpol.2014.05.016.

Büker, P., Morrissey, T., Briolat, A., Falk, R., Simpson, D., Tuovinen, J.-P., Alonso, R., Barth, S., Baumgarten, M., Grulke, N., Karlsson, P.E., King, J., Lagergren, F., Matyssek, R., Nunn, A., Ogaya, R., Peñuelas, J., Rhea, L., Schaub, M., Uddling, J., Werner, W., Emberson, L.D., 2012. DO3SE modelling of soil moisture to determine ozone flux to forest trees. Atmos. Chem. Phys. 12, 5537-5562. http:// dx.doi.org/10.5194/acp-12-5537-2012.

Calatayud, V., Cerveró, J., Calvo, E., García-Breijo, F.-J., Reig-Armiñana, J., Sanz, M.J., 2011. Responses of evergreen and deciduous Quercus species to enhanced ozone levels. Environ. Pollut. 159, 55-63. http://dx.doi.org/10.1016/ j.envpol.2010.09.024.

Calatayud, V., Marco, F., Cerveró, J., Sánchez-Peña, G., Sanz, M.J., 2010. Contrasting ozone sensitivity in related evergreen and deciduous shrubs. Environ. Pollut. 158, 3580-3587. http://dx.doi.org/10.1016/j.envpol.2010.08.013.

De Temmerman, L, Vandermeiren, K. D'Haese, D, Bortier, K, Asard, $\mathrm{H}$. Ceulemans, R., 2002. Ozone effects on trees, where uptake and detoxification meet. Dendrobiology 47.

Dixon, M., Le Thiec, D., Garrec, J.P., 1998. Reactions of Norway spruce and beech trees to 2 years of ozone exposure and episodic drought. Environ. Exp. Bot. 40, 77-91.

Dizengremel, P., Le Thiec, D., Hasenfratz-Sauder, M.-P., Vaultier, M.-N., Bagard, M., Jolivet, Y., 2009. Metabolic-dependent changes in plant cell redox power after ozone exposure. Plant Biol. 11, 35-42. http://dx.doi.org/10.1111/j.14388677.2009.00261.x.

Elvira, S., Alonso, R., Gimeno, B.S., 2007. Simulation of stomatal conductance for Aleppo pine to estimate its ozone uptake. Environ. Pollut. 146, 617-623. http:// dx.doi.org/10.1016/j.envpol.2006.08.008.

Emberson, L.D., Ashmore, M.R., Cambridge, H.M., Simpson, D., Tuovinen, J.-P., 2000a. Modelling stomatal ozone flux across Europe. Environ. Pollut. 109, 403-413.

Emberson, L.D., Wieser, G., Ashmore, M.R., 2000b. Modelling of stomatal conductance and ozone flux of Norway spruce: comparison with field data. Environ. Pollut. 109, 393-402.

Emberson, L.D., Ashmore, M.R., Simpson, D., Tuovinen, J.-P., Cambridge, H.M., 2001 Modelling and mapping ozone deposition in Europe. Water Air Soil Pollut. 130, $577-582$.

Emberson, L.D., Büker, P., Ashmore, M.R., 2007. Assessing the risk caused by ground level ozone to European forest trees: a case study in pine, beech and oak across different climate regions. Environ. Pollut. 147, 454-466. http://dx.doi.org/ 10.1016/j.envpol.2006.10.026.

Feng, Z., Tang, H., Uddling, J., Pleijel, H., Kobayashi, K., Zhu, J., Oue, H., Guo, W., 2012. A stomatal ozone flux-response relationship to assess ozone-induced yield loss of winter wheat in subtropical China. Environ. Pollut. 164, 16-23. http:/ 
dx.doi.org/10.1016/j.envpol.2012.01.014.

Fuhrer, J., 1994. The critical level for ozone to protect agricultural crops - an assessment of data from European open-top chamber experiments. In: Fuhrer, J., Achermann, B. (Eds.), Critical Levels for Ozone - a UN-ECE Workshop Report. Swiss Federal Research Station for Agricultural Chemistry and Environmental Hygiene. Liebefeld-Bern, pp. 42-57.

Grünhage, L., Pleijel, H., Mills, G., Bender, J., Danielsson, H., Lehmann, Y., Castell, J.-F., Bethenod, O., 2012. Updated stomatal flux and flux-effect models for wheat for quantifying effects of ozone on grain yield, grain mass and protein yield. Environ. Pollut. 165, 147-157. http://dx.doi.org/10.1016/j.envpol.2012.02.026.

Jarvis, P.G., 1976. The interpretation of the variations in leaf water potential and stomatal conductance found in canopies in the field. Philos. Trans. Royal Soc. B: Biol. Sci. 273, 593-610. http://dx.doi.org/10.1098/rstb.1976.0035.

Jones, H.G., 1992. Plants and Microclimate: a Quantitative Approach to Environmental Plant Physiology, second ed. Cambridge University Press, Cambridge, UK.

Karlsson, P.E., Uddling, J., Skärby, L., Wallin, G., Selldén, G., 2003. Impact of ozone on the growth of birch (Betula pendula) saplings. Environ. Pollut. 124, 485-495. http://dx.doi.org/10.1016/S0269-7491(03)00010-1.

Karlsson, P.E., Uddling, J., Braun, S., Broadmeadow, M., Elvira, S., Gimeno, B.S., Le Thiec, D., Oksanen, E., Vandermeiren, K., Wilkinson, M., Emberson, L., 2004. New critical levels for ozone effects on young trees based on AOT40 and simulated cumulative leaf uptake of ozone. Atmos. Environ. 38, 2283-2294. http://dx.doi.org/10.1016/j.atmosenv.2004.01.027.

Karlsson, P.E., Braun, S., Broadmeadow, M., Elvira, S., Emberson, L., Gimeno, B.S., Le Thiec, D., Novak, K., Oksanen, E., Schaub, M., Uddling, J., Wilkinson, M., 2007. Risk assessments for forest trees: the performance of the ozone flux versus the AOT concepts. Environ. Pollut. 146, 608-616. http://dx.doi.org/10.1016/ j.envpol.2006.06.012.

Larcher, W., 2003. Physiological Plant Ecology: Ecophysiology and Stress Physiology of Functional Groups, fourth ed. Springer, Berlin, Heidelberg, New York.

LRTAP Convention, 2010. Manual on Methodologies and Criteria for Modelling and Mapping Critical Loads \& Levels and Air Pollution Effects, Risks and Trends. In: Chapter 3: Mapping Critical Levels for Vegetation.

Marzuoli, R., Gerosa, G., Desotgiu, R., Bussotti, F., Ballarin-Denti, A., 2009. Ozone fluxes and foliar injury development in the ozone-sensitive poplar clone Oxford (Populus maximowiczii $\times$ Populus berolinensis): a dose-response analysis. Tree Physiol. 29, 67-76.

Matyssek, R., Karnosky, D.F., Wieser, G., Percy, K., Oksanen, E., Grams, T.E.E., Kubiske, M., Hanke, D., Pretzsch, H., 2010. Advances in understanding ozone impact on forest trees: messages from novel phytotron and free-air fumigation studies. Environ. Pollut. 158, 1990-2006. http://dx.doi.org/10.1016/ j.envpol.2009.11.033.

Medlyn, B.E., Badeck, F.-W., De Pury, D.G.G., Barton, C.V.M., Broadmeadow, M. Ceulemans, R., De Angelis, P., Forstreuter, M., Jach, M.E., Kellomäki, S., 1999. Effects of elevated [CO2] on photosynthesis in European forest species: a metaanalysis of model parameters. Plant Cell Environ. 22, 1475-1495.

Mills, G., Pleijel, H., Braun, S., Büker, P., Bermejo, V., Calvo, E., Danielsson, H. Emberson, L., Fernández, I.G., Grünhage, L., Harmens, H., Hayes, F., Karlsson, P.E., Simpson, D., 2011. New stomatal flux-based critical levels for ozone effects on vegetation. Atmos. Environ. 45, 5064-5068. http://dx.doi.org/10.1016/ j.atmosenv.2011.06.009.

Musselman, R., Lefohn, A., Massman, W., Heath, R., 2006. A critical review and analysis of the use of exposure- and flux-based ozone indices for predicting vegetation effects. Atmos. Environ. 40, 1869-1888. http://dx.doi.org/10.1016/ j.atmosenv.2005.10.064

Oksanen, E., 2003. Physiological responses of birch (Betula pendula) to ozone: comparison between open-soil-grown trees exposed for six growing seasons and potted seedlings exposed for one season. Tree Physiol. 23, 603-614.

Oren, R., Sperry, J.S., Katul, G.G., Pataki, D.E., Ewers, B.E., Phillips, N., Schäfer, K.V.R. 1999. Survey and synthesis of intra-and interspecific variation in stomatal sensitivity to vapour pressure deficit. Plant. Cell Environ. 22, 1515-1526.

Ottosson, S., Wallin, G., Skärby, L., Karlsson, P.-E., Medin, E.-L., Räntfors, M, Pleijel, H., Selldén, G., 2003. Four years of ozone exposure at high or low phosphorus reduced biomass in Norway spruce. Trees 17, 299-307.

Paoletti, E., Contran, N., Bernasconi, P., Günthardt-Goerg, M.S., Vollenweider, P., 2009. Structural and physiological responses to ozone in Manna ash (Fraxinus ornus L.) leaves of seedlings and mature trees under controlled and ambient conditions. Sci. Total Environ. 407, 1631-1643. http://dx.doi.org/10.1016 j.scitotenv.2008.11.061.

Pell, E.J. Sinn, J.P., Brendley, B.W. Samuelson, L., Vinten-Johansen, C., Tien, M. Skillman, J., 1999. Differential response of four tree species to ozone-induced acceleration of foliar senescence. Plant Cell Environ. 22, 779-790.

Pinheiro, J., Bates, D., DebRoy, S., Sarkar, D., The R Development Core Team, 2015 Nlme: Linear and Nonlinear Mixed Effects Models. R package version 3.1-120.

Pleijel, H., Danielsson, H., Emberson, L., Ashmore, M.R., Mills, G., 2007. Ozone risk assessment for agricultural crops in Europe: further development of stomatal flux and flux-response relationships for European wheat and potato. Atmos. Environ. 41, 3022-3040. http://dx.doi.org/10.1016/j.atmosenv.2006.12.002.

Pollastrini, M., Desotgiu, R., Cascio, C., Bussotti, F., Cherubini, P., Saurer, M. Gerosa, G., Marzuoli, R., 2010. Growth and physiological responses to ozone and mild drought stress of tree species with different ecological requirements. Trees 24, 695-704. http://dx.doi.org/10.1007/s00468-010-0439-4.

Reich, P.B., 1987. Quantifying plant response to ozone: a unifying theory. Tree Physiol. 3, 63-91.

Schaub, M., 2005. Physiological and foliar symptom response in the crowns of Prunus serotina, Fraxinus americana and Acer rubrum canopy trees to ambient ozone under forest conditions. Environ. Pollut. 133, 553-567. http://dx.doi.org 10.1016/j.envpol.2004.06.012.

Sun, G., McLaughlin, S.B., Porter, J.H., Uddling, J., Mulholland, P.J., Adams, M.B. Pederson, N., 2012. Interactive influences of ozone and climate on streamflow of forested watersheds. Glob. Change Biol. 18, 3395-3409. http://dx.doi.org/ 10.1111/j.1365-2486.2012.02787.x.

Tarvainen, L., Wallin, G., Räntfors, M., Uddling, J., 2013. Weak vertical canopy gradients of photosynthetic capacities and stomatal responses in a fertile Norway spruce stand. Oecologia 173, 1179-1189. http://dx.doi.org/10.1007/s00442-0132703-y.

Uddling, J., Hall, M., Wallin, G., Karlsson, P.E., 2005. Measuring and modelling stomatal conductance and photosynthesis in mature birch in Sweden. Agric. For. Meteorol. 132, 115-131. http://dx.doi.org/10.1016/j.agrformet.2005.07.004.

Uddling, J., Pleijel, H., Karlsson, P.E., 2004. Measuring and modelling leaf diffusive conductance in juvenile silver birch, Betula pendula. Trees 18, 686-695. http:/ dx.doi.org/10.1007/s00468-004-0353-8.

Wittig, V.E., Ainsworth, E.A., Naidu, S.L., Karnosky, D.F., Long, S.P., 2009. Quantifying the impact of current and future tropospheric ozone on tree biomass, growth physiology and biochemistry: a quantitative meta-analysis. Glob. Change Biol. 15, 396-424. http://dx.doi.org/10.1111/j.1365-2486.2008.01774.x.

Zhang, W., Feng, Z., Wang, X., Niu, J., 2012. Responses of native broadleaved woody species to elevated ozone in subtropical China. Environ. Pollut. 163, 149-157. http://dx.doi.org/10.1016/j.envpol.2011.12.035. 